\title{
Working-Class Youth in the Vanguard: Youth Surveys and their Implications
}

\author{
P. J. Brown
}

For citation: Brown P. J. Working-Class Youth in the Vanguard: Youth Surveys and their Implications. Vestnik of Saint Petersburg University. History, 2019, vol. 64, iss. 3, pp. 913-936. https://doi.org/10.21638/11701/spbu02.2019.306

Between 1935 and 1936 the party conducted a series of surveys to ascertain Soviet youths' cultural and political upbringing, political activism, and material condition. Although ostensibly random, the survey targeted youth, who attended the best schools and who worked or studied at the most technologically advanced factories, the goal being to revel in the success of Soviet education and the high cultural, political, and material level of young workers in the USSR. The survey's results revealed the horrid conditions in which most youth lived and their surprisingly low material and cultural level. Following the 1935-1936 survey, the party spearheaded projects to overhaul and democratize youth organizations (Soviet schools and universities and the Komsomol) and to transform young Soviet workers' living conditions, particularly in dormitories and barracks in working-class districts.

Keywords: working-class, workers, youth, Komsomol (VLKSM), surveys, Soviet Union, Kosarev, Stalin, Great Terror, VUZ, FZU.

\section{Молодежь рабочего класса в авангарде: молодежные опросы и их последствия}

П. Дж. Браун

Для цитирования: Brown P. J. Working-Class Youth in the Vanguard: Youth Surveys and their Implications // Вестник Санкт-Петербургского университета. История. 2019. Т. 64. Вып. 3. С. 913-936. https://doi.org/10.21638/11701/spbu02.2019.306

В период с 1935 по 1936 г. партия провела серию опросов для выявления культурной и политической зрелости молодежи, их политической активности и материального состояния. Несмотря на кажущуюся случайность опрос был нацелен на молодежь, которая посещала лучшие школы и работала или училась на самых передовых заводах, с целью насладиться успехом советского образования и высоким политическим и материальным уровень молодых рабочих в СССР. Результаты опроса показали ужасные условия, в которых проживало большинство молодых людей, и их низкий материальный и культурный уровень. После опроса партия возглавила проекты, направленные

Patrick J.Brown - M.A. in History, Doctoral candidate, Brandeis University, 415 South Street, Waltham, MA, USA, 02453-2728, pjbrown@brandeis.edu

Патрик Дж. Браун - магистр, аспирант, Университет Брандейса, США, 02453-2728415, Уалтам, Массачусетс, Южная ул., 415; pjbrown@brandeis.edu

Funding: Fulbright US Student Grant (2015-2016)

Финансирование: студенческий грант Фулбрайта США (2015-2016)

(C) Санкт-Петербургский государственный университет, 2019 
на перестройку и демократизацию молодежных организаций (например, школы, университеты и комсомол) и изменение жизненных условий молодых советских рабочих, особенно в общежитиях и поселковых бараках.

Ключевые слова: рабочий класс, рабочие, молодежь, комсомол (ВЛКСМ), опросы, Советский Союз, Косарев, Сталин, Большой террор, вуз, ФЗУ.

In November 1935 Joseph Stalin announced "Life has improved, comrades. Life has become more joyous" ${ }^{1}$. Such changes could not necessarily be observed in Soviet polices: the five-year-plans (FYP) and collectivization continued, (even if the latter was pursued at a more moderate rate), but state rhetoric softened. It was not just rhetoric that changed; 1934 to mid-1936 were relatively good years for common workers. The Soviet Union's bread basket had begun to recover from the famine following collectivization, and the results were beginning to show up on stores' shelves. As populations urbanized and new markets emerged, production increased, and the production of consumer goods relative to industrial goods grew as well. Technological advancements not only made it so that a larger subset could have access to goods, but film and radio were used to promote consumer goods. Strides in public education and the expansion of literacy also caused printing industries to boom. In short, the FYPs' unprecedented industrial expansion dramatically increased the possibility of mass consumption: mass production meant that a wider range of people - not just the elite but commoners as well - had access to material and cultural goods. The party sought to mobilize and politicize this nascent consumer culture among the youth. The focus on the younger generation was paramount: the children of the 1930s grew up entirely under the Soviet system and were completely unburdened by capitalism's legacies and vices. They were also the most educated generation of Russians ever and had unprecedented access to theatre, films, and literature. The potentials were endless: unlike the previous generation, youth in the first Soviet generation learned to read, think, speak, and write under the Bolshevik system ${ }^{2}$. In 1935-1936, the party conducted a survey designed to celebrate the educational, material, and cultural level of the youth; the survey's disappointing results, however, drove the state to overhaul organizations that worked with youth and to invest more in areas where young workers lived.

Little scholarship exists on the condition of youth in the 1930s despite the existence of material on wages, use of time, reading habits, and the conditions of areas where youth lived, worked, and studied. Western works that focus on young workers tend to examine a small cadre of educated and upwardly mobile engineers and managers (vydvizhentsy) who supported Stalinist policies and interventions because they afforded them opportunities for advancement. While fascinating, such studies are limited in scope because they focus on a small sub-stratum of the workforce - the new Soviet intelligentsia ${ }^{3}$. Russian works concentrate on this group as well in order to chart the training of skilled cadres necessary for victory in the Great Fatherland War ${ }^{4}$. Youth organizations - namely the Komsomol -

1 Stalin J. V. Works. Vol. 14: 1934-1940. London, 1978. P. 98.

2 Hoffman D. Stalinist Values: The Cultural Norms of Soviet Modernity, 1917-1941. Ithaca, 2003. P. $118-119$.

${ }^{3}$ Fitzpatrick S.: 1) The Cultural Front: Power and Culture in Revolutionary Russia. Ithaca, 1992; 2) Education and Social Mobility in the Soviet Union, 1921-1934. New York, 1979.

4 Serebrianskaia G. Promyshlennost' i kadry Volgo-Viatskogo regiona Rossiiskoi Federatsii v kontse 30-kh-pervoi polovine 40-kh godov XX veka. Nizhnii Novgorod, 2003; Vdovin M. Vse dlia pobedy!: ocherki istorii oboronnoi promyshlennosti Gor'kovskoi oblasti: 1930-1945 gg. Nizhnii Novgorod, 2010; Promysh- 
have also attracted attention. Western scholars tend to focus on the Komsomol in the 1920s and demonstrate how the expansion of state control in the FFYP transformed it from a relatively independent organization to the one that served the regime's interests of political socialization and societal control ${ }^{5}$. Studies that examine the Komsomol in the 1930s explore the organization's transformation from a small workers' organization with little influence to an influential mass organization. They cite citing the important role the Komsomol played in creating productive, cultured, politically loyal, and militarily prepared communist youth. Such studies foreground the important role the Great Terror and war played in shaping the Komsomol's composition and influence as well as in forming youth culture and identity ${ }^{6}$. This study connects these seemingly aligned but disconnected historiographies. It examines the disappointing results of a 1935-1936 survey on young workers' educational level, material condition, cultural upbringing, and political activism, and charts the transformative organizational and infrastructural changes that followed.

The focus of this study is the 1935-1936 survey of young workers and students. This study presents union-wide data as well as data for the three areas most represented in the random sample - Moscow, Ivanovo, and Gorky - when applicable. The focus on Moscow - the capital - and two other cities allows it to demonstrate center-peripheral differences in youth upbringing. The focus on Ivanovo, a region specializing in textile production, and Gorky, a heavy industrial center, demonstrates differences between youth employed in heavy and light industry. The study focuses disproportionately on Gorky, for which a full sample was conducted. Within the Gorky Oblast, the study examines the region's two largest factories, Krasnoe Sormovo - an old prerevolutionary machine building and ship building factory - and the Gorky Auto Factory (GAZ) - the FFYPs automotive showcase. Through a focus on the two factories, the study analyzes differences in upbringing and living conditions of the youth in two very different industrial districts: the old Sormovo district, with developed institutions, practices, and norms, and the new avtozavod district, which had no existing institutions, but to which the state devoted much more resources, envisioning it as a utopian socialist city (sotsgorod). The study also seeks to understand how the party apparatus in Gorky responded to the survey. It examines investigations into organizations and institutions that worked with the youth. Above all, it demonstrates that the survey's disconcerting results directed the party's attention to deficiencies in their work and launched a purge in institutions dealing with young workers.

lenno-khoziaistvennaia elita Nizhegorodskoi oblasti 1917-1996 / eds L. Belous, O. Kolobov, V.Smirnov. Nizhnii Novgorod, 1996.

${ }^{5}$ Gorsuch A. Youth in Revolutionary Russia: Enthusiasts, Bohemians, Delinquents. Bloomington, 2000; Neumann M. The Communist League and the Transformation of the Soviet Union, 1917-1932. New York, 2001; Gooderham P. The Komsomol and the Worker Youth: The Inculcation of 'Communist Values in Leningrad during NEP // Soviet Studies. 1982. No. 4. P. 506-528.

6 Bernstein S. Raised under Stalin: Young Communists and the Defence of Socialism. Cornell, 2017; Fisher R. A Pattern for Soviet Youth: A Study of the Congresses of the Komsomol, 1918-1954. New York, 1959; Grekhov V. Rasprava s rukovodstvom Komsomola v 1937-1938 godakh // Voprosy istorii 1990. No. 11. P.136-151; Krivoruchenko V. Molodezh', коmsomol, obshchestvo 30-kh godov XX stoletiia: k probleme repressii v molodezhnoi srede. Moscow, 2011; Trushchenko N. Kosarev. Moscow, 1988. 


\section{The 1935-1936 Survey of Young Workers and Students}

In order to revel in their success in raising this new generation of youth, the state launched a survey of young industrial workers and students. Although Gosplan's Central Administration of Economic Accounting (TsUNKhU), did not specifically state that the survey's results were to be used as propaganda, its requirement that Komsomols poll the "best" workers and students certainly suggests that it was interested in creating an optimistic rather than a realistic and practical survey of young workers ${ }^{7}$. The survey endeavored to present a productive, cultured, well-educated, politically engaged, and materially well-off working class. It focused on major points of the Soviet Union's first two FYPs, the idea being that young workers from areas that received more educational, cultural, and economic investment would return better results (Tab. 1) ${ }^{8}$.

Table 1. Composition by City

\begin{tabular}{|l|c|}
\hline \multicolumn{1}{|c|}{ City } & Percent \\
\hline Moscow & 17.93 \\
\hline Ivanovo & 14.14 \\
\hline Gorky & 10.96 \\
\hline Dnepir & 9.76 \\
\hline Leningrad & 9.56 \\
\hline Donets & 9.16 \\
\hline Kharkov & 8.76 \\
\hline Stalino & 7.77 \\
\hline Kadievko & 5.98 \\
\hline Orekhovo Zuevo & 5.98 \\
\hline
\end{tabular}

S o u r ce: [(Blanki obsledovaniia kul'tury i byta rabochei i studencheskoi molodezhi // RGAE. F. 1562. Op. 15. D. 848. L. 1-363 ob.; D. 849. L. 1-277 ob.; D. 850 . L. 1-538 ob.; D. 851. L. 1-378 ob.; D. 852. L. 1-472 ob.; D. 853. L. 1-500 ob.; D. 854 . L. 1-407 ob.; D. 855. L. 1-262 ob.. D. 856 . L. 1-337 ob.; D. 857. L. 1-260 ob.; D. 858. L. 1-128 ob.; D. 859. L. 1-170 ob.; D. 860 . L. 1-365 ob.; D. 861 . L. 1-180 ob.; D. $862 . \quad$ L. 1-416 ob.; D. 863 . L. 1-438 ob.) - hereafter Survey of young workers and students].

7 Provedeniia obsledovaniia kul'tury i byta rabochei i studencheskoi molodezhi // Rossiiskii gosudarstvennyi arkhiv ekonomiki (hereafter - RGAE). F. 1562. Op. 15. D. 847. L. 113.

${ }^{8}$ Ibid. L. 113-113 ob. 
The party mobilized local Komsomols to conduct a survey of young workers under the age of 26 . The vast majority (91.6\%) of the workers surveyed were older than 17 , and $63.6 \%$ were between 18 and 22 years of age (Tab. 2).

Table 2. Age of Workers Surveyed

\begin{tabular}{|c|c|}
\hline Age & Percent \\
\hline 15 to 17 & 8.40 \\
\hline 18 & 13.80 \\
\hline 19 & 10.40 \\
\hline 20 & 13.60 \\
\hline 21 & 14.40 \\
\hline 22 & 11.40 \\
\hline 23 & 8.80 \\
\hline 24 & 8.20 \\
\hline 25 & 11.00 \\
\hline
\end{tabular}

S o u r c e: Survey of young workers and students.

Although the surveys were ostensibly random, Gosplan instructed local Komsomols to poll young workers at the Soviet Union's largest and most technologically advanced factories in order to enhance its propagandic effect, the hope being that workers at those factories would reflect better on Soviet upbringing and local Komsomols' work ${ }^{9}$. The majority of workers surveyed were from factories engaging in heavy industrial production: only $22.54 \%$ worked in light industry and a disproportionate amount came from prestigious and highly technical lines - machine building, metallurgy, and automotive (Tab. 3).

Table 3. Representation in Sample, by Industry

\begin{tabular}{|l|c|}
\hline \multicolumn{1}{|c|}{ Industrial Line } & Percent \\
\hline Machine Building & 31.46 \\
\hline Light industry & 22.54 \\
\hline Metallurgy & 14.32 \\
\hline Automotive & 9.86 \\
\hline Engine & 9.86 \\
\hline Mining & 8.92 \\
\hline Energy & 3.05 \\
\hline
\end{tabular}

S o u r c e: Survey of young workers and students.

${ }^{9}$ Provedeniia obsledovaniia kul'tury i byta rabochei i studencheskoi molodezhi. L. 113. 
Gosplan also instructed Komsomols to poll workers in "large main shops." That focus expedited the survey process, but also ensured that the Komsomol could target workers in "leading occupations." In the case of machine work, a TsUNKhU directive - approved by Stalin - required Komsomols to survey "machinists, turners, forgers, mechanics, drillers, millers, and riveters"10. Local Komsomols also targeted young workers who had more education and who attended the best performing schools. For example, the majority of Krasnoe Sormovo workers polled either attended the factory apprenticeship school (shkola fabichno-zavodskogo uchenichestva - hereafter FZU) or two schools which primarily served the sons and daughters of the plant's intelligentsia ${ }^{11}$. As a result, the educational level of the workers surveyed was much higher than the average education of young Soviet workers (Tab. 4).

Table 4. Education Level of Young Workers in the USSR

\begin{tabular}{|l|c|c|c|c|c|c|c|}
\hline \multirow{2}{*}{$\begin{array}{c}\text { Years of } \\
\text { Education }\end{array}$} & \multirow{2}{*}{$\begin{array}{c}\text { Urban } \\
\text { Workers, } \\
\text { USSR }\end{array}$} & \multicolumn{6}{|c|}{ Surveyed Workers } \\
\cline { 3 - 8 } & USSR & Moscow & Ivanovo & Gorky & GAZ & KS \\
\hline 0 to 3 Years & 50.92 & 16.93 & 20.00 & 52.11 & 19.44 & 18.53 & 19.13 \\
\hline 4 to 6 Years & 36.45 & 40.84 & 27.78 & 42.23 & 35.73 & 38.61 & 37.16 \\
\hline 7 or more Years & 12.64 & 42.23 & 52.22 & 5.63 & 44.83 & 42.86 & 43.72 \\
\hline
\end{tabular}

S o u r c e: Survey of young workers and students; TsUNKhU. Kul'turnoe stroitel'stvo SSSR: Statisticheskii sbornik. Moscow, 1940. P. 51.

In order to inflate the study's educational and technical results, Gosplan instructed Komsomols to give "preference to workers enrolled in an institute of higher education (Vysshee uchebnoe zavedenie - hereafter VUZ)" - technical institutes (tekhnikumy), FZUs, and universities ${ }^{12}$. In contrast to the $4.26 \%$ of youth who attended VUZes between 1928 and 1936, $26.14 \%$ of workers surveyed attended these institutions (Tab. 5).

Table 5. VUZ Attendance among Respondents

\begin{tabular}{|c|c|c|c|c|c|}
\hline USSR & Moscow & Ivanovo & Gorky & GAZ & KS \\
\hline 26.14 & 24.44 & 20.29 & 37.15 & 26.75 & 40.45 \\
\hline
\end{tabular}

S o u r c e: Survey of young workers and students; TsUNKhU. Kul'turnoe stroitel'stvo SSSR: Statisticheskii sbornik. Moscow, 1940. P.111; Zhiromskaia V., Kiselev I., Poliakov Iu. Polveka pod grifom "sekretno": vsesoiuznaia perepis' naseleniia 1937 g. Moscow, 1996. P. 67.

Although educational statistics reflect selective sampling, they also reveal greater trends. They highlight a difference in the educational level of heavy industrial and light industrial workers: over $40 \%$ of young workers in the USSR had 7 or more years of edu-

${ }_{10}$ Provedeniia obsledovaniia kul'tury i byta rabochei i studencheskoi molodezhi. L. 86.

11 Blanki obsledovaniia kul'tury i byta rabochei i studencheskoi molodezhi // RGAE. F. 1562. Op. 15. D. 848. L. 1-363 ob.; D. 849. L. 1-277 ob.

12 Telegram ot narodnogo komissariata zdravookhraneniia RSFSR tsentral'nogo nauchnoissledovatel'skogo instituta okhrany zdorov'ia detei i podrostkov v TsUNKhU, sector truda otdel biudzhetov // RGAE. F. 1562. Op. 15. D. 847. L. 109. 
cation, but only $5.63 \%$ of Ivanovo youth had 7 or more years of schooling. The data also reflects a center-peripheral divide in regards to educational infrastructure (Tab. 4). While Moscow had many ten-year schools (desiatiletki), other regions had seven-year schools (semiletki), with Ivanovo having primarily four and five-year schools ${ }^{13}$. High VUZ attendance among Gorky workers reflects the fact that Gorky - called the city of VUZes (gorod VUZov) - had more VUZes per capita than any other province in the USSR. The heightened number of VUZ students among Krasnoe Sormovo youth reflects the fact that the plant's FZU was the oldest and largest in the region (with the exception of the university $)^{14}$.

Ensuring that respondents had a high political level was also critical. As a result, Gosplan instructed the Komsomol to poll more of its own members - considered the political and cultural vanguard of the youth ${ }^{15}$. Whereas $12 \%$ of youth in the country between 15 and 24 years of age were Komsomol members, $47.81 \%$ of polled workers were Komsomol members (Tab. 6) ${ }^{16}$. The party and the Komsomols hoped that a disproportionate representation of Komsomol members would reflect greater political and cultural activism among the youth.

Table 6. Komsomol Members among Respondents

\begin{tabular}{|c|c|c|c|c|c|}
\hline USSR & Moscow & Ivanovo & Gorky & GAZ & KS \\
\hline 47.81 & 55.56 & 28.17 & 48.11 & 54.44 & 44.26 \\
\hline
\end{tabular}

S o u r c e: Survey of young workers and students.

The results demonstrated that the Komsomol had a stronger presence in heavy industrial regions and at new factories like GAZ. Part of the reason for heightened Komsomol membership in these regions was investment; Komsomol organs in Moscow - the political capital - and GAZ - a focal point of the FFYP - were better funded and thus attracted more youth. Such regions also typically appealed more to party activists because they had better living conditions and offered activists greater opportunity for advancement. These were not the only reasons why certain areas and plants had more Komsomol members than others; much like the party, the Komsomol privileged workers engaging in heavy industry over those in light industry. Membership was typically higher among youth in newer plants as well. Komsomol membership at older plants was lower because long established hierarchies, based on one's connections in the region, were often more determinant of advancement than one's status in the Komsomol. As a result, young workers at old plants often chose to forego Komsomol membership because they benefitted less from it than workers at newer plants ${ }^{17}$.

13 Blanki obsledovaniia kul'tury i byta rabochei i studencheskoi molodezhi // RGAE. F. 1562. Op. 15. D. 848. L. 1-363 ob.; D. 849. L. 1-277 ob.; D. 850. L.1-538 ob.; D. 851. L.1-378 ob.; D. 853. L. 1-500 ob.; D. 854. L. 1-407 ob.

14 TsUNKhU. Kul'turnoe stroitel'stvo SSSR: Statisticheskii sbornik. Moscow, 1940. P. 116.

15 Provedeniia obsledovaniia kul'tury i byta rabochie i studencheskoi molodezhi // RGAE. F. 1562. Op. 15. D. 847. L. 113.

16 Bernstein S. Raised under Stalin: Young Communists and the Defense of Socialism. Ithaca, 2017. P. 229.

17 Vystuplenie sekretariata Gor'kovskogo obkoma VKP(b) AN Burova na IV plenume obkoma VLKSM ot 18 fevraliia 1937 g. // GOPANO. F. 3. Op. 1. D. 48. L. 18. 
The survey demonstrated that Soviet youth were productive. More education also resulted in greater norm fulfilment, even though more educated workers were typically in higher ranked positions with higher quotas (Tab. 7). Since factories as a whole were not meeting quotas, high rates of norm fulfillment among the youth suggested that older experienced workers were not meeting their norms and were improperly ranked. Seniority-based promotion, a common practice at many plants, drove down norms, production rates, and stifled initiative. The state had long been trying to curtail such practices, most recently with the promotion of Stakhanovism and the implementation of standardized technical exams in $1933^{18}$.

Table 7. Education and Norm Fulfillment

\begin{tabular}{|l|c|c|}
\hline \multicolumn{1}{|c|}{ Years of Education } & Norm Fulfillment, USSR & Norm Fulfillment, Gorky \\
\hline 0 to 3 Years & 105.15 & 112.24 \\
\hline 4 to 6 Years & 115.94 & 113.16 \\
\hline 7 or more Years & 123.58 & 128.66 \\
\hline Total & 113.49 & 119.93 \\
\hline
\end{tabular}

S o u r c e: Survey of young workers and students.

The state also hoped to revel in its youth's skill as demonstrated by their scores on the state technical examination (gosudarstvennyi technicheskii ekzamen) (hereafter - GTE). The GTE standardized skill rankings and occupational placements were designed to curtail blat, patronage, and seniority-based hiring practices. The examinations also promoted the education of common workers at factories. Local factory officials claimed that the state devoted much attention to the training of specialist cadres during the FFYP, but "ignored the education of ordinary workers", an important task given the expansion of the workforce ${ }^{19}$. Early attempts to promote the GTE were unsuccessful: by February 1935, only 6.32 percent of the 4,254 Krasnoe Sormovo workers eligible to take the exam had taken $i^{20}$. Through public shaming and socialist competitions, the state compelled workers to take the examinations ${ }^{21}$. The number of workers studying for and taking the exams expanded rapidly: by March 25 1935, 44.14 percent of Sormovo workers were studying to take the exams, and 34.93 percent had taken them, with 90.29 percent of those workers passing $\mathrm{it}^{22}$.

${ }_{18}$ Rech' na prieme tiazheloi promyshlennosti o perspektivakh razvertyvaniia stakhanovskogo dvizheniia v tiazheloi promyshlennosti pri narkomtiazhprome 13 noiabria 1935 goda // Rossiiskii gosudarstvennyi arkhiv sotsial'no-politicheskoi istorii (RGASPI). F. 85. Op.29. D. 100. L.1-5.

19 Sostoianie raboty po tekhminimu i sdache sotstekhekzamenov na predpriiatiiakh gor'kovskogo kraia // Gosudarstvennyi obshchestvenno-politicheskii arkhiv Nizhegorodskoi oblasti (hereafter GOPANO). F. 4523. Op.2. D.324. L. 119.

20 Svodka rezul'tatov gostekhekzamena po zavodu Krasnoe Sormovo na 21 fevralia 1935 goda // Krasnyi sormovich. 1935. No.45. P.1.

${ }^{21}$ O rabote s komsomolom // Krasnyi sormovich. 1935. No.80. P.1; Svodka khoda podgotovki i rezul'tatov gostekhekzamena zavoda "Krasnoe Sormovo" na 19 marta 1935 goda // Krasnyi sormovich. 1935. No. 64. P. 1; Svodka khoda podgotovki i rezul'tatov gostekhekzamena zavoda "Krasnoe Sormovo" na 25 marta 1935 goda // Krasnyi sormovich. 1935. No.70. P.1.

22 Idid. 
The state expected that the survey's results would demonstrate similar success on the examinations, but this did not prove to be the case.

Table 8. Exam Result among Respondents

\begin{tabular}{|l|c|c|c|c|c|c|}
\hline \multicolumn{1}{|c|}{ Exam Result } & USSR & Moscow & Ivanovo & Gorky & GAZ & KS \\
\hline Not Taken & 8.57 & 12.22 & 1.41 & 8.01 & 3.46 & 8.20 \\
\hline Unsatisfactory (2) & 36.85 & 32.22 & 49.30 & 32.97 & 32.31 & 33.88 \\
\hline Satisfactory (3) & 4.98 & 6.67 & 4.23 & 10.83 & 6.15 & 14.75 \\
\hline Good (4) & 21.51 & 16.67 & 23.94 & 29.98 & 32.31 & 25.14 \\
\hline Excellent (5) & 28.09 & 32.22 & 21.13 & 18.21 & 25.77 & 18.03 \\
\hline
\end{tabular}

S o u r c e: Survey of young workers and students.

The results were disheartening, especially given the fact that these were supposedly the best young workers. Most young workers had taken the exam but did not perform well: 36.85 percent failed the exam, underscoring limitations in educational training (Tab. 8). The results were worse in Ivanovo because less attention was devoted to training workers in textiles, an industry which continued to rely disproportionately on apprenticeships to instruct the younger generation. Education also seemed to have a marginal impact on how young workers performed on the GTE (Tab. 9). In the USSR, workers with 7 or more years of education only scored 8.6 percent better than workers with 0 to 3 years of education ${ }^{23}$.

Table 9. Education and State Technical Exam (GTE) Results

\begin{tabular}{|l|c|c|c|c|}
\hline $\begin{array}{c}\text { Years of } \\
\text { Education }\end{array}$ & $\begin{array}{c}\text { GTE Score, } \\
\text { USSR }\end{array}$ & $\begin{array}{c}\text { GTE Score, } \\
\text { Gorky }\end{array}$ & $\begin{array}{c}\text { GTE Score, } \\
\text { GAZ }\end{array}$ & $\begin{array}{c}\text { GTE Score, } \\
\text { KS }\end{array}$ \\
\hline 0 to 3 Years & 3.18 & 2.95 & 3.05 & 2.89 \\
\hline 4 to 6 Years & 3.53 & 3.34 & 3.49 & 3.16 \\
\hline 7 or more Years & 3.61 & 3.55 & 3.76 & 3.55 \\
\hline Total & 3.45 & 3.36 & 3.53 & 3.30 \\
\hline
\end{tabular}

S o u r c e: Survey of young workers and students.

Even those young workers with VUZ training scored below expectations. The party expected that all VUZ graduates would score a 4 or higher on the GTE because the courses trained young workers in the material on the GTEs, exams which regular workers should pass. VUZ graduates did not average a 4 or higher on the exams and many of them only scored marginally better than workers without higher education (Tab. 10).

${ }^{23}$ Blanki obsledovaniia kul'tury i byta rabochei i studencheskoi molodezhi // RGAE. F. 1562. Op. 15. D. 848. L. 1-363 ob.; D. 849. L.1-277 ob.; D.850. L.1-538 ob.; D. 851. L.1-378 ob.; D. 852. L. 1-472 ob.; D. 853. L. 1-500 ob.; D. 854. L. 1-407 ob.; D. 855. L.1-262 ob.; D. 856. L.1-337 ob.; D. 857. L. 1-260 ob.; D. 858. L.1-128 ob.; D. 859. L.1-170 ob.; D.860. L.1-365 ob.; D. 861. L.1-180 ob.; D. 862. L.1-416 ob.; D. 863. L. $1-438 \mathrm{ob}$. 
Table 10. VUZ Attendence and GTE Results

\begin{tabular}{|l|c|c|c|c|}
\hline \multicolumn{1}{|c|}{ Category } & $\begin{array}{c}\text { GTE Score, } \\
\text { USSR }\end{array}$ & $\begin{array}{c}\text { GTE Score, } \\
\text { Gorky }\end{array}$ & $\begin{array}{c}\text { GTE Score, } \\
\text { GAZ }\end{array}$ & $\begin{array}{c}\text { GTE Score, } \\
\text { KS }\end{array}$ \\
\hline VUZ Graduates & 3.66 & 3.64 & 3.77 & 3.85 \\
\hline Non-VUZ Graduates & 3.36 & 3.19 & 3.44 & 2.93 \\
\hline Percent Difference in Scores & 5.69 & 8.91 & 6.55 & 18.47 \\
\hline
\end{tabular}

S o u r c e: Survey of young workers and students.

Not all VUZ graduates even passed the exams: 13.33 percent at Krasnoe Sormovo failed, 22.53 percent in Gorky failed, and 31 percent in the USSR failed the examinations ${ }^{24}$.

The party also hoped all workers, but especially young ones, would continue their education after graduating from secondary schools or VUZes. The survey's results demonstrated that youth rarely pursued further education. Although Komsomol members were more likely to continue their education because it furthered their advancement within the party, only a little more than 50 percent of them did so (Tab. 11).

Table 11. Respondents Continuing to Study

\begin{tabular}{|l|c|c|c|c|c|c|}
\hline \multicolumn{1}{|c|}{ Continuing Studying } & USSR & Moscow & Ivanovo & Gorky & GAZ & KS \\
\hline All & 40.84 & 40.00 & 38.03 & 30.41 & 37.31 & 24.59 \\
\hline Komsomol Members & 55.83 & 54.90 & 50.00 & 38.76 & 50.36 & 35.37 \\
\hline
\end{tabular}

S o u r ce: Survey of young workers and students.

Youth continuing their education was less common at factories like Krasnoe Sormovo, where one's education had less to do with advancement in the factory's ranks. The location of youth housing was also critical. Whereas youth at GAZ lived near the factory in the utopian sotsgorod, most young workers at Krasnoe Sormovo lived in working-class districts (poselki) 8-13 kilometers from the factor $\mathrm{y}^{25}$. Given the poor state of public transportation, getting to and from work and school was difficult for many, and made them less likely to pursue further education.

The regime was also bothered by the low material level of respondents. In some regards the survey's results were promising: they demonstrated that young workers earned about the same amount as older counterparts. At Krasnoe Sormovo the average worker in 1936 earned 242 rubles and the average youth polled earned a little more than 226 rubles $^{26}$. It is important to remember, however, that the workers polled were the most successful

${ }^{24}$ Blanki obsledovaniia kul'tury i byta rabochei i studencheskoi molodezhi // RGAE. F. 1562. Op. 15. D. 848. L.1-363 ob.; D. 849. L.1-277 ob.; D. 850. L.1-538 ob.; D. 851. L.1-378 ob.; D. 852. L. 1-472 ob.; D. 853. L.1-500 ob.; D. 854. L.1-407 ob.; D. 855. L.1-262 ob.; D. 856. L. 1-337 ob.; D. 857. L. 1-260 ob.; D. 858. L.1-128 ob.; D.859. L.1-170 ob.; D. 860. L.1-365 ob.; D. 861. L.1-180 ob.; D. 862. L.1-416 ob.;

D. 863 . L. $1-438$ ob.

${ }^{25}$ Stenogramma XI raionnoi partiinoi konferentsii s 3 maia po 5 maia 1937 g. // GOPANO. F. 34. Op. 1. D. 1508. L.73-74.

26 Ibid. L. 15. 
youth, and even among them there was much differentiation in salaries that demonstrated how difficult life could be. The upper $10^{\text {th }}$ percentile of young workers earned 3 times as much as the lower $10^{\text {th }}$ percentile of workers, and 25 percent of young workers only earned a little more than 150 rubles (Tab. 12). Youth earnings seem particularly low, considering that a Sormovo party member claimed that "the majority of youth cannot afford enough food if they earn under 300 rubles" ${ }^{\prime 27}$.

Table 12. Salary of Respondents

\begin{tabular}{|l|c|c|c|c|c|c|}
\hline \multicolumn{1}{|c|}{ Salary } & USSR & Moscow & Ivanovo & Gorky & GAZ & KS \\
\hline Average Salary & 236.40 & 264.29 & 209.07 & 237.67 & 249.02 & 226.63 \\
\hline Upper $10^{\text {th }}$ Percentile & 370 & 373 & 326 & 385 & 400 & 360 \\
\hline Upper $25^{\text {th }}$ Percentile & 275 & 300 & 234 & 300 & 308 & 264 \\
\hline Median & 204 & 250 & 198 & 206 & 230 & 206 \\
\hline Lower $25^{\text {th }}$ Percentile & 157 & 200 & 150 & 160 & 174 & 150 \\
\hline Lower $10^{\text {th }}$ Percentile & 120 & 155 & 121 & 120 & 136 & 120 \\
\hline
\end{tabular}

S o u r c e: Survey of young workers and students.

The survey also demonstrated that the housing crisis remained a reality of young workers' lives.

Table 13. Living Situation for Respondents

\begin{tabular}{|l|c|c|c|c|c|c|}
\hline \multicolumn{1}{|c|}{ Living Situation } & USSR & Moscow & Ivanovo & Gorky & GAZ & KS \\
\hline In Own Apartment & 47.47 & 50.56 & 40.85 & 51.5 & 55.64 & 43.96 \\
\hline Rent Corner & 23.03 & 17.98 & 38.03 & 37.91 & 34.24 & 48.9 \\
\hline Live in Dorm & 29.49 & 31.46 & 21.13 & 10.58 & 10.12 & 7.14 \\
\hline
\end{tabular}

S o u r ce: Survey of young workers and students.

Even though the sample targeted well-off workers, a significant portion of them rented a corner in an apartment. Only in the most developed and crowded regions - Moscow, Leningrad, and the Donbass - had a large number of workers moved into dorms; most continued to reside in apartments or corners. Old industrial regions, such as Gorky, depended on existing housing stock when possible to avoid devoting scant resources to new construction (Tab. 13). This was especially the case in the Sormovo district, where most workers lived in cramped housing in the villages surrounding the factory.

Although consumer production and distribution increased, the survey showed that Soviet youth owned less clothing than prerevolutionary workers. The average youth polled owned roughly 4 changes of clothing, with some owning much less and others owning much more (Tab. 14). Such results demonstrated no improvement from the prerevolu-

27 Soveshchaniia zhen inzhenerno-tekhnicheskikh rabotnikov predpriiatii gor. Gor'kogo ot 5-go aprelia 1936 g. // GOPANO. F. 30. Op. 1. D. 1421. L. 2-4. 
tionary period, during which time young single workers spent enough money on their clothing to purchase two to three new changes of clothes each year ${ }^{28}$.

Table 14. Number of Clothing Items Owned by Respondents

\begin{tabular}{|l|c|c|}
\hline \multicolumn{1}{|c|}{ Clothing Item } & USSR & Gorky \\
\hline Coats & 1.52 & 1.81 \\
\hline Suits & 0.78 & 0.87 \\
\hline Pants or Skirts & 2.29 & 2.61 \\
\hline Wool Dresses* & 1.21 & 1.56 \\
\hline Cotton Dresses* & 3.25 & 3.36 \\
\hline Jackets & 0.75 & 0.72 \\
\hline Shirts & 3.75 & 4.09 \\
\hline Socks & 3.98 & 3.56 \\
\hline Shoes & 1.91 & 2.1 \\
\hline
\end{tabular}

* Women only.

S o u r ce: Survey of young workers and students.

Industrialization and the increased production of consumer products did, however, lead to youth owning more consumer goods (Tab. 15).

Table 15. Percent of Respondents, who Owned Products

\begin{tabular}{|l|c|c|}
\hline \multicolumn{1}{|c|}{ Product } & USSR & Gorky \\
\hline Radio & 22.71 & 26.13 \\
\hline Gramaphone & 5.98 & 3.76 \\
\hline Musical Instruments & 28.09 & 34.12 \\
\hline Camera & 3.78 & 5.32 \\
\hline Bike & 6.77 & 9.55 \\
\hline Skis & 16.93 & 45.38 \\
\hline Skates & 26.89 & 35.84 \\
\hline Chess & 11.35 & 12.21 \\
\hline
\end{tabular}

S o u r c e: Survey of young workers and students.

The most concerning result of the study was youths' cultural level. In order to assess the political and cultural education of young workers, the survey asked whether they had

28 Prokopovich S. Biudzhety peterburgskikh rabochikh, 1909 g. St. Petersburg, 1909. P. 15-17; Srednie godichnye tseny na glavneishie zhizennye pripasy v g. Moskve za 1913-1815 i 1922-1925 gg. 
Table 16. Percent of Respondents, who Read the Following Works

\begin{tabular}{|l|c|c|}
\hline \multicolumn{1}{|c|}{ Literature } & USSR & Gorky \\
\hline Lenin to the $3^{\text {rd }}$ Komsomol Conf. & 43.82 & 49.14 \\
\hline Stalin to the XVII Party Conf. & 69.32 & 72.61 \\
\hline State and Revolution & 15.34 & 17.06 \\
\hline Imperialism as the Highest Stage of Capitalism & 29.88 & 29.42 \\
\hline Marx's Kapital & 15.74 & 11.27 \\
\hline
\end{tabular}

S o u r c e: Survey of young workers and students.

read party literature and literary works assigned in schools. The regime expected to relish in young workers' political and cultural education, but the results were disappointing.

The survey revealed that workers seldom read political literature, particularly older works. Stalin's speech to the most recent party congress (the XVII) was the only one that more than half of the respondents had read. Nearly half of the youth had also read Lenin's Speech to the $3^{\text {rd }}$ Komsomol Congress, which outlined the organization's roles and goals. Despite Lenin's and Marx's theoretical works being assigned in schools, few workers read these texts, so critical to understanding the economic relations undergirding Soviet communism (Tab. 16). While working-class youth read literary fiction more often than Marxist-Leninist cannon, the party expected the vast majority, if not all workers, to have read the works included in the survey because they were assigned in schools (Tab. 17).

Table 17. Percent of Respondents, who Read the Following Works

\begin{tabular}{|l|c|c|}
\hline \multicolumn{1}{|c|}{ Literature } & USSR & Gorky \\
\hline Mother & 61.95 & 66.04 \\
\hline Eugene Onegin & 52.79 & 57.90 \\
\hline Virgin Soil Upturned & 50.60 & 57.75 \\
\hline Dead Soul & 44.91 & 49.37 \\
\hline The Iron Flood & 38.84 & 49.14 \\
\hline Fathers and Sons & 36.25 & 38.81 \\
\hline How the Steel is Tempered & 36.85 & 25.35 \\
\hline Peter the First & 31.27 & 31.77 \\
\hline Anna Karenina & 29.48 & 27.39 \\
\hline A Man Changes his Skin & 25.30 & 17.53 \\
\hline I Love & 22.91 & 13.93 \\
\hline Ninety-Three & 14.34 & 12.99 \\
\hline Jean-Christophe & 8.37 & 5.95 \\
\hline
\end{tabular}

S o u r c e: Survey of young workers and students. 
The state was also interested in how often young workers attended various cultural institutions, whether they be museums, lectures, or the theatre. Many in the party believed unengaged youth would drink and commit petty crimes. As a result, it encouraged youth to visit cultural institutions not only because they distributed propaganda, but also because they pulled youth off the streets. Overall, the results discouraged the party because they hoped youth would visit cultural institutions more often. The survey's results were quite informative as well: they illustrated limited youth interest in lectures, sporting events, and museums, but also demonstrated the propagandic potential of film as a medium (Tab. 18).

Table 18. Visits to Cultural Institutions over 3 Months

\begin{tabular}{|l|c|c|}
\hline \multicolumn{1}{|c|}{ Cultural Institution } & USSR & Gorky \\
\hline Movie Theatre & 9.08 & 10.73 \\
\hline Theatre & 3.58 & 3.49 \\
\hline Lectures & 0.85 & 0.67 \\
\hline Museums & 0.57 & 0.32 \\
\hline Sporting Events & 0.18 & 0.31 \\
\hline
\end{tabular}

S o u r c e: Survey of young workers and students.

Although the overall survey yielded disappointing results, the party published carefully selected individual responses to celebrate the cultural and material level of the youth and their political engagement. Material from the survey appeared frequently in Soviet newspapers and occasionally in communist party literature abroad ${ }^{29}$. TsUNKhU also ensured that the survey's unfavorable results would not be published. The party permitted the Institute for the Protection of the Health of Youth and Adolescents to analyze the results of the survey, but required the organization to sign a statement affirming that they would not "publish any information from the survey without the prior consent of TsUNKhU"30.

\section{Responses to the Survey}

The survey's disappointing and unexpected results brought long-standing issues to Moscow's attention and launched national and local investigations to explain the results, to root out those responsible for the shortcomings it identified, and to remedy those shortcomings. The party mobilized district committees, the Komsomol, and the press corps to investigate working-class districts and barracks, where many youth lived and where party presence was minimal ${ }^{31}$. Organizations working with youth - specifically the Komsomol and universities - and their staff found themselves under increasing scrutiny. Unlike the survey, these investigations did not focus on the best young workers, and as a result, they

29 Sormovo rabotat' luchshee, byt vperedi // Leninskaia smena. No. 19. P. 3; Life is More Joyous // The New Masses. June 16. 1936. P. 17-18.

30 Telegram ot narodnogo komissariata zdravookhraneniia RSFSR tsentral'nogo nauchnoissledovatel'skogo instituta okhrany zdorov'ia detei i podrostkov v TsUNKhU, sector truda otdel biudzhetov, 27-go oktiabriia 1936 g. // RGAE. F. 1562. Op.15. D. 847. L. 111.

${ }^{31}$ Stenogramma XI raionnoi partiinoi konferentsii s 3 maia po 5 maia 1937 g. // GOPANO. F. 34. Op. 1. D. 1508. L. 9-12. 
returned even more disconcerting results. The goal of these investigations also influenced their results: the inquires did not seek to trumpet successes but rather to find problems and root out those responsible.

Investigations into living conditions in working-class districts underscored the party's failure. Much of that failure centered on housing. While the state reveled in the fact that it constructed 52,000 sq. meters of housing in the Sormovo District during the SFYP, such figures did not mean that the amount of living space per worker increased. In fact, the amount of living space per worker had fallen from 3.4 sq. meters in 1934 to 3.2 sq. meters by January $1937^{32}$. Part of the problem was population increase; the district's population increased from 65,000 in 1934 to 74,000 in 1937, but such growth did not explain the decrease in housing per worker. The decrease in living space was due to the fact that the factory relocated workers in private housing to factory housing ${ }^{33}$. In 1930, Krasnoe Sormovo only housed 33.81 percent of its workforce, but by April 1936, 47 percent of workers had resided in factory housing ${ }^{34}$. Another problem was that the factory replaced FFYP temporary wooden construction with stone housing. Rather than perform costly repairs on wooden housing stock, the administration destroyed much of it and replaced with stone housing ${ }^{35}$. The destruction of quickly built and shoddily constructed wooden housing meant that much of Sormovo's housing construction in the SFYP did little to remedy the housing crisis. The problem did not just exist in Sormovo; at GAZ many workers were housed in short-term wooden housing during the FFYP because stone materials were required to build the plant. Due to the scarcity of stone materials, 89.3 percent of construction at the plant was wooden in 1932, and it was not until 1935 that stone construction surpassed wooden construction at GAZ. At GAZ, 45 percent of wooden housing built before 1935 no longer existed in $1938^{36}$. As a result of all these factors, the amount of housing per worker in many industrial districts declined and remained well under the 6 sq. meter goal ${ }^{37}$.

The housing situation was particularly bad in the Komsomol'skii working-class district. Komsomolskii was the first Soviet working-class district at Krasnoe Sormovo and was envisioned as a showcase, but due to shortages, most initial construction was of wooden 2-story 8-apartment- barracks ${ }^{38}$. A 1937 rabkor (workers' correspondents) investigation revealed that although these barracks were designed to house 30 workers, they housed 200, with 15 to 17 workers living in large common areas ${ }^{39}$. Not all workers in Komsomol'skii lived in such cramped conditions: a large stone barrack housed 312 FZU students, 6 to a

${ }^{32}$ Stenogramma XI raionnoi partiinoi konferentsii s 3 maia po 5 maia 1937 g. L. 9.

33 Ibid. L. 9-12.

34 Perspektivnyi plan zhilishchnogo stroitel'stva zavoda Krasnoe Sormovo PARVAGDIZa // GOPANO. F. 4523. Op.1. D. 167. L.161; Soveshchaniia zhen inzhenerno-tekhnicheskikh rabotnikov predpriiatii gor. Gor'kogo ot 5-go aprelia 1936 g. // GOPANO. F.30. Op.1. D. 1421. L. 6 ob.

35 Stenogramma XI raionnoi partiinoi konferentsii s 3 maia po 5 maia 1937 g. // GOPANO. F. 34. Op. 1. D. 1508. L. 12.

36 Sekretariu VTsSPS lichno NM Shernik predsedatel'iu TsK soiuza lichno PA Borisovu dokladnaia zapiska o sostoianii zhilfondam o bespechennosti zhiloploshchad'iu na avtozavod molotova // Tsentral'nyi arkhiv Nizhegorodskoi oblasti (hereafter - TsANO). F. 2435. Op. 7. D. 13. L. 466-470.

37 Stenogramma XI raionnoi partiinoi konferentsii s 3 maia po 5 maia 1937 g. // GOPANO. F. 34. Op. 1. D. 1508. L. 9-12.

38 VSNKh gosudarstvennye zavody 'Krasnoe Sormovo' svedenie po zhilistroitel'stvu gosudarstvennykh zavodov Krasnoe Sormovo // TsANO. F. 15. Op.1. D. 1712. L.231-232.

39 Komsomol'skii poselok // Leninskie smeny. 1937. No. 66. P. 4. 
room, with each student having 4 sq. meters of living space, but even that building was in a state of disrepair by $1936^{40}$. The poor condition of barracks was demonstrative of how many workers left. According to rabkor representatives, many youths left because they "believe it is better to live in the shanty homes constructed in the countryside" 41 . Another report illustrated that in 7 months, 500 of the 593 construction workers living in one dorm left, with most leaving in January, likely because the dorm had no heat ${ }^{42}$.

Representatives at party conferences identified several reasons for the poor conditions in working-class districts and dorms. Some of course parroted old tropes underscoring low-discipline, drunkenness, and religiosity among those residing in working-class districts, where many people came from the countryside to work at Gorky's numerous construction projects during the FYPs ${ }^{43}$. Such explanations, while common, were unlikely: conditions and behavior at the FZU dorm, which housed mainly workers' sons, were just as poor. Other representatives pointed out social and economic problems that impacted those living in working-class districts. One representative emphasized that most youth residing in dorms earned well under 300 rubles a month ${ }^{44}$. The situation was even worse for students: in December 1937, a second ranked student earned 73.5 rubles on average ${ }^{45}$. Youth earning less than 300 rubles a month could not afford to take the train to work and school. Given that most working-class districts were between 8 and 13 kilometers from the plant, taking the train was crucial, especially for students who often attended school (for 6 hours) and worked at the plant (for four or more hours) ${ }^{46}$. According to the Komsomol press, workers frequently arrived at work late because they could not afford to ride the train ${ }^{47}$. Dormitories were poorly maintained and supplied as well. According to a party member assigned to one of the Komsomol'skii dorms: "Workers have no blankets or pillows, and the rooms are filthy and infested with cockroaches" 48 .

The party's lack of presence in working-class districts was at the crux of most problems. Weak party presence in the districts and dorms not only meant that the Bolsheviks had limited knowledge of life there, but also that such districts received less funding for programming, development, and maintenance. The 52-room FZU barrack in the Komsomol'skii District only had 2 Bolsheviks in it ${ }^{49}$. The party also excoriated the rabkor for paying so little attention to working-class districts and for allowing deteriorating conditions there to go unaddressed ${ }^{50}$. (Only after such critiques did the rabkor begin writing

40 Stenogramma soveshchaniia direktorov, sekretariei partkomov, pred profkomov i sekretarei komietetov Vuzov i tekhnikomov for gor'kogo ot 22 dekabria 1937 goda // GOAPNO. F. 30. Op. 1. D. 1794. L. 1.

${ }^{41}$ Komsomol'skii poselok // Leninskie smeny. 1937. No. 66. P. 4.

42 V barikakh gor'kpromstroia // Krasnyi sormovich. 1939. No. 220. P. 1.

43 Stenogramma soveshchaniia direktorov, sekretariei partkomov, pred profkomov i sekretarei komietetov Vuzov i tekhnikomov for gor'kogo ot 22 dekabria 1937 goda // GOAPNO. F. 30. Op. 1. D. 1794. L. 5, 7 ob., 13 ob.

44 Ibid.

45 Ibid.

46 Ibid.

47 Komsomol'skii poselok // Leninskie smeny. 1937. No. 66. P. 4.

48 Stenogramma soveshchaniia direktorov, sekretariei partkomov, pred profkomov i sekretarei komietetov Vuzov i tekhnikomov for gor'kogo ot 22 dekabria 1937 goda // GOAPNO. F. 30. Op. 1. D. 1794. L. 5, 7 ob., 13 ob.

49 Ibid. L. 1.

50 Stenogramma XI raionnoi partiinoi konferentsii s 3 maia po 5 maia 1937 g. // GOPANO. F. 34. Op. 1. D. 1508. L. 115. 
daily articles on the horrid conditions in working-class districts and barracks.) Low-living conditions in the districts and in dorms ensured that few Bolshevik cadres wanted to live or work there. The Komsomol'skii district, which housed over 7,000 workers in 1936, did not even have a bath house ${ }^{51}$. A rabkor investigation also revealed that residents stood in line for an hour just to get water ${ }^{52}$. Stores in working-class districts were also poorly allocated; the bread store in the Koopertivnyi District served 3,000 workers and the one in Komsomol'skii served 7,000. A party representative at the 1937 district conference asserted: "Workers wait in line for two hours just to get bread, and if they want other goods they wait in another queue for 2 more hours" 53 . In Komsomol'skii it was reported that "the queue for bread forms at 3 p.m. and the last workers do not move through the line until 10 p.m" ${ }^{54}$. The stores also did not receive all their supply. As a party member at the 1937 conference said: "We have stores, but there is great difficulty with supply because drivers refuse to go there. There are always interruptions in supply and shortages because the road is unpassable" 55 . The food situation was reportedly so bad in workers' districts that many worked seasonally and returned to the village in the summer ${ }^{56}$.

Socio-economic strife made hooliganism a major problem in working-class districts and dorms. Hooliganism, which appeared as a category in the late imperial period, continued to be used in the Soviet period to describe youths' actions that disrupted social order, such as drinking, playing cards, and fighting. In March 1935, Stalin announced a new crime - aggravated hooliganism - which included more serious offenses such as armed robbery and assault. How hooliganism was seen by the highest ranks of the party also shifted: before 1935, hooliganism was considered to be the result of boredom, but from 1935 on, acts of hooliganism came to be seen as political and anti-Soviet behavior ${ }^{57}$. A. Kosarev, the First Secretary of the Komsomol, proclaimed that among hooligans there was "an active organizing core of class enemies... for whom hooliganism is a form of political activity" 58 .

The youth were often both the victims and the perpetrators of hooliganism. An article in the Komsomol press, "The enemy stands on the hooligan's back," revealed that hooligans in the Komsomol'skii District "frequently terrorize youth returning from work and school"59. According to representatives at the 1937 district conference, travelling to and from the factory after dark was so dangerous that workers left work early to avoid attacks ${ }^{60}$. Hooliganism was particularly common in the FZU barrack, where youth destroyed furniture and dishes and even engaged in political hooliganism, defacing portraits of Stalin and writing anti-party messages on dishware ${ }^{61}$. In order to drum up a moral

51 Stenogramma XI raionnoi partiinoi konferentsii s 3 maia po 5 maia 1937 g. L. 136.

52 Ocheredi za vodoi // Krasnyi sormovich. 1939. No. 43. P. 4.

53 Stenogramma XI raionnoi partiinoi konferentsii s 3 maia po 5 maia 1937 g. L. 71.

${ }^{54} \mathrm{~K}$ otvetu vinovnikov // Krasnyi sormovich. 1935. No. 18. P. 3.

55 Stenogramma XI raionnoi partiinoi konferentsii s 3 maia po 5 maia 1937 g. L. 67 ob.

56 Soveshchaniia zhen inzhenerno-tekhnicheskikh rabotnikov predpriiatii gor. Gor'kogo ot 5-go aprelia 1936 g. // GOPANO. F. 30. Op. 1. D. 1421. L. 16.

57 Bernstein S. Raised under Stalin. P. 97.

58 Ibid.

59 Za spinoi khuligana stoit vrag // Leninskie smeny. 1937. No. 67. P. 1.

60 Stenogramma XI raionnoi partiinoi konferentsii s 3 maia po 5 maia 1937 g. L. 192

${ }^{61}$ Ibid.; Stenogramma soveshchaniia direktorov, sekretariei partkomov, pred profkomov i sekretarei komietetov Vuzov i tekhnikomov for gor'kogo ot 22 dekabria 1937 goda // GOAPNO. F. 30. Op. 1. D. 1794. L. 79 . 
panic, the press published fear mongering accounts of attacks and emphasized the need to intensify policing measures against hooligans because "they do not fear the repercussions of the police" 62 .

Despite Moscow and the press branding hooligans as "class enemies", most at the 1937 Sormovo District Conference continued to suggest that boredom caused hooliganism and underscored the failure of Soviet institutions. One representative asserted: "Hooliganism and drunkenness are at the crux of the youths' problems because youth are raised neither by the school nor their family, but by the streets" ${ }^{3}$. School attendance was a problem in Sormovo because often youth began working at an early age (15.42 years of age according to the 1935-1936 survey) and had to travel 8-13 kilometers between the factory and their school district. Whereas school attendance was greater than 90 percent among school-aged workers in the Central Industrial Region, only a little more than 60 percent of school-aged workers at Krasnoe Sormovo went to school ${ }^{64}$. Party representatives also attacked officials for poor maintenance of workers' clubs, for the lack of cultural institutions near youth residences, and for failing to craft political and cultural programs that sparked youths' interests. A rabkor investigation revealed that workers' clubs and "red corners" in Komsomol'skii were either closed or in a state of disrepair; in fact, residents stripped the valuables out of the clubs and sold them ${ }^{65}$. The house of culture in Sormovo had fallen into disrepair as well, and, according to party representatives, there were no Komsomol cadres there, "people just go there to brawl" ${ }^{6}$. Other cultural institutions, such as theatres, did not exist in working-class districts, and if they did, they were of a much lower quality than the ones that existed in city centers. In order to go to sport fields, the palace of culture, a library, or the movie theatre, young workers had to travel into the center of Sormovo. And even though Krasnoe Sormovo was a large factory that employed over 15,000 workers, cultural institutions there were substandard: workers complained that "the theatres in Gorky and Kanavino have sound and show new movies, but in Sormovo we have no sound and only show Chapaev and Three Tales of Lenin"67.

A review of the study habits of youth at the largest enterprises in Gorky also yielded poor results. A March 1937 study found that at the 7 largest enterprises in the city only 2,432 youths were enrolled in technical courses and only 957 in Stakhanovite courses ${ }^{68}$. The rate of attrition was even worse; by August 1937 enrolment in technical minimum circles was 66.45 percent of what it was in March, and enrolment in Stakhanovite courses was 52.21 percent of its March level ${ }^{69}$. An investigation of GTE results found that exam performance was much worse than was suggested by the Komsomol survey. The study revealed that in Gorky only 54.39 percent of test takers passed the exam (Tab. 19).

Organizations that dealt with the youth were particularly targeted in the initial phases of the Great Terror. That focus resulted from party investigations and surveys that revealed corruption and deficiencies in organizations that worked with young workers. Ini-

\footnotetext{
${ }^{62}$ Rabotat' v massa molodezhi byt vo glave mass // Leninskie smeny. 1937. No. 67. P. 1.

63 Stenogramma XI raionnoi partiinoi konferentsii s 3 maia po 5 maia 1937 g. L. 73-4.

64 Ibid.

65 Komsomol'skii poselok / / Leninskie smeny. 1937. No. 66. P. 4.

${ }^{66}$ Stenogramma XI raionnoi partiinoi konferentsii s 3 maia po 5 maia 1937 g. L. 107 ob.

67 Trebovaniia martenovtsev k domu kul'tury // Krasnyi sormovich. 1935. No. 23. P. 1.

${ }^{68}$ Itogi reida proverki sostoianiia tekhnicheskoi ucheby rabochikh po predpriiatiiami NKTP gor'kovskoi oblasti // GOPANO. F.30. Op. 1. D. 1694. L.3.

69 Ibid.
} 
Table 19. GTE Results, 1937

\begin{tabular}{|l|c|c|c|c|c|c|}
\hline \multicolumn{1}{|c|}{ Factories } & Took GTE & Padded GTE & Percent Passed & Percent 5s & Percent 4s & Percent 3s \\
\hline 16 Gorky Factories & 25.034 & 13.617 & 54.39 & 11.08 & 22.79 & 20.53 \\
\hline of which GAZ & 6173 & 3.275 & 53.05 & 11.92 & 24.91 & 16.22 \\
\hline of which KS & 2.857 & 1.353 & 47.36 & 10.12 & 21.11 & 16.14 \\
\hline
\end{tabular}

S o u r ce: Itogi polugodnoi tekhucheby rabochikh na gorodskikh predpriiatiiakh // GOPANO. F. 30. Op. 1. D. 1694. L. 34.

tially, purges in these organizations targeted malfeasant officials, who failed to implement state policy and follow directives, but the purge quickly degenerated into an attack on morality. The slogan "everyday life is politics" (byt - eto politika) and the promotion of Communist morals (kommunisticheskie morally) launched an attack on immoral behavior $^{70}$. This assault was specifically aimed at youth organizations, where superiors were accused of corrupting the youth, holding drunken parties, and engaging in improper relationships toward women (ne komsomolskikh otnoshenie $k$ zhenshchine $)^{71}$. Those who came under scrutiny included a broad category of "officials who saw corruption but remained silent", in addition to those directly engaging in immoral behavior ${ }^{72}$. As a result, almost anyone in a position of power or oversight could be targeted for failing to notify the party of transgressions.

Universities and their staff came into criticism for their failure to educate the youth. Professors were disproportionately targeted in the initial stages of the Great Terror in Gorky. Philosophical and pedagogical faculties were hit by the purge; in December 1935 and January 1936, 20 pedagogical professors were arrested for failing to teach economic materialism and party history ${ }^{73}$. These purges predated 27 January 1936, when an article appeared in Pravda that critiqued M.N. Pokrovskii (the deceased head of the Red Professoriate) and launched a purge of history faculty, who "continue to insist on historical definitions and conditions grounded in the well-known errors of Pokrovskii" "74. Overall, teachers and professors composed 9.64 percent of purge victims in Gorky, with most of those purged being in VUZes ${ }^{75}$. Between 1936 and 1938, 77 FZU professors and at least 96 professors at technical institutes were arrested ${ }^{76}$. The regime also targeted students with questionable class backgrounds. In 1938 alone, the NKVD investigated and arrest-

${ }^{70}$ O resheniiakh IV Plenuma TsK VLKSM rezoliutsiia po dokladu tov. Beloborodova // Leninskaia smena. 8 Sept. 1937. P. 1.

${ }^{71}$ Byt - eto politika // Leninskaia smena. 14 Sept 1937. P. 1.

72 Moral'nyi oblik bol'shevika // Leninskaia smena. 22 Sept 1937. P. 2.

${ }_{73}$ Material otdela shkol i kul'tprosve raboty gorkoma $\mathrm{k}$ otchetu gorkom po vuzam i tekhnikami // GOPANO. F. 30. Op. 1. D. 2136. L.21-6, 33-4; Spravka otdela shkol i nauki Gor'kovskogo obkoma VKP(b) o prepodavanii obshchestvenno-politicheskikh distsiplin v vuzakh goroda "Pokonchit's politicheskoi bespechnost'iu na vazhneishem uchastke raboty vuzov // GOPANO. F. 3. Op. 1. D. 304. L. 86-93.

74 "V Sovnarkome soiuza SSSR I TsK VKP(b)" // Pravda. 23 Jan. 1936. P. 2.

75 Liagushkina L. Sotsial'nyi portret repressirovannykh v RSFSR v khode bol'shogo terrora (19371938 gg.): Sravnitel'nyi analiz baz dannykh po regional'nym 'knigam pamiati'. Moscow, 2016. P. 136-145, 351.

${ }^{76}$ Material otdela shkol i kul'tprosve raboty gorkoma $\mathrm{k}$ otchetu gorkom po vuzam i tekhnikami // GOPANO. F.30. Op. 1. D.2136. L.21-26, 33-34. 
ed members from 34 anti-Soviet youth groups in pedagogical institutes, arguing that the groups had "improper attitudes toward hooliganism and drinking"77.

National and local Komsomols were also subject to purging. In July and August 1937, over 70 percent of the Komsomol's Central Committee was removed and arrested, leaving hard-liner Kosarev and a group of his closest allies as the only high-ranking Komsomol leaders remaining ${ }^{78}$. The Komsomol purge targeted passive cadres, hooligans, and "Trotskyist degenerates" - drunks, philanderers, and reprobates, who used their positions to corrupt the youth ${ }^{79}$. Given the level of drinking among the Komsomol leadership, there was no shortage of enemies; even Kosarev - a notorious drinker - issued a self-critique entitled "On my drinking bouts" 80.

The imprisonment of the Gorky Komsomol occurred in two stages, the first of which took place before the purge of the national Komsomol. The uncovering of "Trotskyist degenerate," V. Sorotkin, among the Gorky Komsomol leadership, led Kosarev to launch a mass checking of the Komsomol in spring $1937^{81}$. Mass removals of high-ranking Komsomol leaders occurred over the next year beginning with the removal of K. Beloborodov, the head of the Gorky Komsomol, and his closest allies. The purge focused on Komsomol agitators in military organizations, who allowed immoral behavior to proliferate in the army, and led to the arrest and execution of 91 high-ranking Komsomol agitators. B. Flaksman, Beloborodov's replacement, soon came under increased criticism and was cited for running a synagogue in his apartment, but his tight knit group of allies in the Komsomol enabled him to weather the accusation, despite much evidence against him ${ }^{82}$. It was not until Kosarev launched a renewed assault on the Gorky Komsomol that Flaksman and his allies were arrested. Kosarev himself attended the Third Plenum of the Gorky Komsomol in May 1938 to ensure that Flaksman and his allies were removed. The attack began with an article in the Gorky paper, which asserted: "Flaksman is not merely a collaborator, but an enemy. A collaborator is a special condition, but an enemy of the people is the unequivocal enemy of our party grouped with Trotskyite-Bukharinists and other scum" ${ }^{83}$. Kosarev's rebukes at the plenum were not just directed at Flaksman, but at the entire organization. He scolded them asserting "The party punishes people for hiding enemies... What kind of leaders are you, if you do not see what is going on right under your noses" 84 . The meeting led to a renewed assault on Komsomol cadres in Gorky: over the course of 1938, the party and the NKVD arrested Komsomol workers in 55 organizations ${ }^{85}$. All in all, over 70 percent of representatives at the $4^{\text {th }}$ Gorky Komsomol Conference in March 1936 were removed from the Komsomol's ranks by the $6^{\text {th }}$ conference in February $1939^{86}$.

77 Krivoruchenko V. Molodezh', Komsomol, Obshchestvo 30-kh godov XX stoletiia: k problem repressii v molodezhnoi srede. Moscow, 2001. P. 94.

78 Gordeeva L. Repressivnyi mekhanizm politicheskoi vlasti // Obshchestvo i vlast': rossiiskaia provintsiia, 1917-1980-e gody. Vol. 2 / ed. by A. Sakharov. Nizhnii Novgorod, 2002. P. 267.

79 Otchet gor'kovskogo obkoma VKP(b) o rabote v 1936 g. // GOPANO. F. 3. Op. 1. D. 34. L. 147-152.

80 Bernstein S. Raised under Stalin. P. 104.

81 Krivoruchenko V. Molodezh', komsomol, obshchestvo. P.91.

82 Otchet otvetstvennogo sekretaria oblastnogo soveta Soiuza voinstvuiushchikh bezbozhnikov Braude v gor'kovskii oblasti za vremia s IV kraevoi partiinoi konferentsii (za 1934, 1935, 1936 gg. i 3 mesiatsa 1937 g.) // TsANO. F. 3074. Op. 1. D.320. L. 148.

83 Krivoruchenko V. Molodezh', komsomol, obshchestvo. P.91.

84 Ibid. P. 92-93.

85 Ibid. P. 94.

${ }^{86}$ Gordeeva L. Repressivnyi mekhanizm politicheskoi vlasti. P. 267. 
Komsomol purges and expulsions disproportionately targeted older Komsomol members, or "pererostki," (overgrown members). Due to a moratorium on party membership from 1933 onwards, the average age of Komsomol members increased from 19.36 in 1933 to 21.75 in $1936^{87}$. Aging membership restricted young members' advancement within the Komsomol as well: whereas 42.7 percent of those with voting rights at the $19319^{\text {th }}$ Komsomol Congress were younger than 23 , only 14.5 percent with voting rights at the $193610^{\text {th }}$ Komsomol Congress were younger than $23^{88}$. Younger workers' interest in the Komsomol also waned: "The problem" one Sormovo Komsomol member claimed "is that the youth do not consider the Komsomol to be an organization that works in their interests" 89 . To combat initiative stifling bureaucratism, the purges disproportionately targeted pererostki: whereas those over 24 years of age made up 30 percent of Komsomol membership, they made up 50 percent of Komsomol members who were purged ${ }^{90}$. An examination of attendees at the $5^{\text {th }}, 6^{\text {th }}$, and $7^{\text {th }}$ Gorky Oblast Komsomol Conferences illustrates the purge's impact on older high-ranking members in the Komsomol, and the opportunities the purges created for Komsomol youth, who had previously found their advancement stymied by older cadres (Tab. 20, 21).

Table 20. Age of Delegates at Gorky Komsomol Conferences, in percent

\begin{tabular}{|l|c|c|c|}
\hline \multicolumn{1}{|c|}{ Age } & $\mathbf{5}^{\text {th }}$ Conference $^{*}$ & $\mathbf{6}^{\text {th }}$ Conference $^{* *}$ & 7 $^{\text {th }}$ Conference $^{* * *}$ \\
\hline Under 20 & 4.76 & 9.56 & 27.57 \\
\hline 20 to 23 & 11.72 & 21.51 & 31.23 \\
\hline 23 to 26 & 30.77 & 16.18 & 25.25 \\
\hline Older than 26 & 52.75 & 52.76 & 15.95 \\
\hline
\end{tabular}

${ }^{\star} 10-14$ Oct. $1937 ;{ }^{* *} 11-16$ Feb. 1939; ${ }^{* *}$ 28-30 Sep. 1940.

Table 21. Tenure of Delegates at Gorky Komsomol Conferences, in percent

\begin{tabular}{|l|c|c|c|}
\hline \multicolumn{1}{|c|}{ VLKSM Tenure } & $\mathbf{5}^{\text {th }}$ Conference & $\mathbf{6}^{\text {th }}$ Conference $^{* *}$ & $\mathbf{7}^{\text {th }}$ Conference $^{* * *}$ \\
\hline 0 to 3 & 12.09 & 20.30 & 38.21 \\
\hline 4 to 6 & 17.58 & 18.61 & 23.57 \\
\hline 7 to 9 & 22.71 & 37.22 & 21.43 \\
\hline 10 to 12 & 28.21 & 15.60 & 14.64 \\
\hline Over 12 & 19.41 & 8.27 & 2.14 \\
\hline
\end{tabular}

*10-14 Oct. 1937; ${ }^{* \star} 11-16$ Feb. 1939; ${ }^{* * *}$ 28-30 Sep. 1940.

S o u r c e: Osokin V. Sostav delegatov V Gor'kovskoi oblastnoi konferentsii VLKSM. URL: http://serg.estile.ru/page4521/ (accessed: 27.08.2018); Osokin V. Sostav delegatov VI Gor'kovskoi oblastnoi konferentsii VLKSM. URL: http://serg.e-stile.ru/page4524/ (accessed: 27.08.2018); Osokin V. Sostav delegatov VII Gor'kovskoi oblastnoi konferentsii VLKSM. URL: http://serg.e-stile.ru/page4527/ (accessed: 27.08.2018).

${ }^{87}$ Bernstein S. Raised under Stalin. P. 232.

88 Ibid. P. 113-114.

89 Vystuplenie sekretariata Gor'kovskogo obkoma VKP(b) AN Burova na IV plenume obkoma VLKSM ot 18 fevraliia 1937 g. // GOPANO. F.3. Op. 1. D. 48. L. 18.

90 Bernstein S. Raised under Stalin. P. 118. 
While the regime's response to the survey brought unjust bloodshed, it also directed state attention to areas in much need of support. The party democratized access to higher education. A greater percentage of those without working-class backgrounds were enrolled in universities: whereas 34.02 percent of all VUZ students were from non-working-class families in 1934, by 1938, 66.1 percent of VUZ students were from non-working-class backgrounds ${ }^{91}$. No longer was Komsomol membership essentially a prerequisite to study at VUZes: 54.18 percent of students in the Gorky Province were Komsomol or party members in 1936, but by 1939 only 25.08 percent were Komsomol or party members ${ }^{92}$. Despite the decline in Komsomol representation among university students, the Komsomol and its influence grew immensely from 1936 to 1941 . Whereas 12 percent of youth between 15 and 24 years of age were in the Komsomol in 1936, 30 percent were in the Komsomol by 1940. Komsomol membership broadened as well; in 1933 workers had the largest representation in the Komsomol, but by 1940 students, kolkhoz workers, and white-collar workers all enjoyed greater representation than workers ${ }^{93}$. Workers' GTE scores rose significantly as well: 45.61 percent of Gorky workers failed the GTEs in 1936, but only 4.1 percent did so in $1939^{94}$. The party also devoted more attention to sports circles and military training among the youth. In Sormovo alone, the party built 3 sport halls, 2 ski areas, and a park between 1936 and 1940. In 1935, under 1,000 young Sormovoites participated in sports societies, but by 1939, Sormovo had 35 sport societies with 9,803 members, over 5,000 of which were under $25^{95}$.

A greater focus on cultural and infrastructural development in working-class districts caused life in those regions to improve. The regime devoted significantly more resources to construction in working-class districts. The paving of Komintern street, which connected downtown Sormovo and working-class districts, made supply between the two much easier. The development of regular bus lines between working-class districts and factories made getting between work, home, school, and cultural institutions simpler. The party also funded the construction of theatres, clubs, stadiums, libraries, bath houses, and banks in working-class districts. It also constructed exemplary educational institutions in working-class districts; by 1939, the districts surrounding Sormovo had three of the best performing schools in the province (nos.77, 82, and 84) ${ }^{96}$. Not all areas saw such improvement. Despite investment, housing continued to be a major problem; in 1939, the amount of living space per person in Sormovo fell to 3.13 sq. meters, a figure that was likely higher among white-collar and ITR personnel and lower among common workers. The continued decrease in living space was not the result of neglect, but rather of the factory housing a greater portion of workers: whereas the factory housed 47 percent of its employees in April 1936, by January 1939, it had housed 98 percent of the its workforce ${ }^{97}$.

91 Kul'turnoe stroitel'stvo SSSR. P. 114.

92 Otchet o rabote tekhnikumov goroda za period iiun' 1938 g po aprel' 1939 god // GOPANO. F. 30. Op.1. D.2136. L.171-2.

93 Bernstein S. Raised under Stalin. P. 231.

94 Otchet o rabote tekhnikumov goroda za period iiun' 1938 g po aprel' 1939 god. L.176; Itogi reida proverki sostoianiia tekhnicheskoi ucheby rabochikh po predpriiatiiami NKTP gor'kovskoi oblasti // GOPANO. F.30. Op.1. D. 1694. L.3.

${ }^{95}$ Material otdela shkol i kul'tprosve raboty gorkoma $\mathrm{k}$ otchetu gorkom po vuzam i tekhnikami // GOPANO. F.30. Op. 1. D.2136. L. 45.

96 Ibid. P. 30.

97 Perspektivnyi plan zhilishchnogo stroitel'stva zavoda Krasnoe Sormovo PARVAGDIZa // GOPANO. F. 4523. Op. 1. D. 167. L. 161; Gody stalinskikh piatiletok // Krasnyi sormovich. 1939. No. 276. P. 1. 


\section{Conclusion}

Much as discussions of the 1936 Constitution alerted the Bolshevik Party to its failures and shortcomings, the shocking results of the 1935-1936 youth survey directed state attention to shortcomings among the Soviet Union's most precious resource - the youth. The survey's results demonstrated that the majority of youth, even the most educated ones, lived in squalid conditions, owned few goods, scored poorly on technical examinations, and were politically uninvolved and even disinterested. The survey led to an increased interest in youths' lives; the party devoted more attention and funding to areas where young workers lived, worked, and studied. Organizations that frequently worked with youth and party agitators in working-class districts and barracks came under much scrutiny as the regime identified those responsible for shortcomings in youth upbringing. Much as in the case of the Constitution, the results of the survey led to false accusations, arrests, and executions, particularly of Komsomol activists and university personnel. In fact, the earliest phases of the Great Terror in Gorky targeted the Komsomol leadership and the professoriate. While the survey and the subsequent investigations and arrests led to unjust bloodshed and terror, they also directed attention to areas in much need of improvement. The survey's and investigations' results led to increased party presence in working-class districts; more party cadres meant more oversight and control, but also greater investment and stark improvements in living conditions. The survey's results also led to the democratization and expansion of many youth organizations. Purges of the Komsomol leadership and subsequent attempts to rebuild and expand the Komsomol transformed it from a small, primarily working-class organization, dominated by older Komsomol cadres, to a mass organization that accepted youth of all types and in which younger members had more opportunity for advancement. A wider swath of the population was also admitted to VUZes: no longer was a working-class background and Komsomol membership a prerequisite to study at a VUZ.

\section{References}

Belous L., Kolobov O., Smirnov V., eds. Industrial and Economic Elite of the Nizhny Novgorod Region 19171996. Nizhnii Novgorod, nauch.-sprav. izd., 1996, 252 p. (In Russian)

Bernstein S. Raised under Stalin: Young Communists and the Defence of Socialism. Cornell, Cornell UP, 2017, $268 \mathrm{p}$.

Dobrokhotov V. Steps of the Komsomol Tribe: Essays on the History of the Gor'kov Regional Organization of the Komsomol. Gor'kii, Volgo-Viatskoe kniznoe izdatel'stvo, 1973, 440 p. (In Russian)

Fisher R. A Pattern for Soviet Youth: A Study of the Congresses of the Komsomol, 1918-1954. New York, Columbia, UP, $452 \mathrm{p}$.

Fitzpatrick S. Education and Social Mobility in the Soviet Union, 1921-1934. New York, Cambridge, UP, $1979,355 \mathrm{p}$.

Fitzpatrick S. Everyday Stalinism: Ordinary Life in Extraordinary Times. Soviet Russia in the 1930s. New York, Oxford, UP, 1999, 288 p.

Fitzpatrick S. The Cultural Front: Power and Culture in Revolutionary Russia. Ithaca, Cornell, UP, 1992, 256 p.

Grekhov V. Violence with the Leadership of the Komsomol in the Years 1937-1938v. Voprosy istorii, 1990, no. 11, pp. 136-151.

Gooderham P. The Komsomol and the Worker Youth: The Inculcation of 'Communist Values in Leningrad during NEP. Soviet Studies, 1982, no. 4, pp. 506-528.

Gordeeva L. Repressive Mechanism of Political Power. Obshchestvo i vlast': rossiiskaia provintsiia, 19171980-e gody, vol.2. Ed. by A.Sakharov. Nizhnii Novgorod, Institut rossiiskoi istorii RAN, 2002, pp. 267-271. (In Russian) 
Gorsuch A. Youth in Revolutionary Russia: Enthusiasts, Bohemians, Delinquents. Bloomington, Indiana, UP, 2000, 288 p.

Hoffman A. Stalinist Values: the Cultural Norms of Soviet Modernity, 1917-1941. Ithaca, Cornell, UP, 2003, $264 \mathrm{p}$.

Krivoruchenko V. Youth, Komsomol, Society of the 30s of the 20 th century: to the Problems of Repression Among the Youth. Moscow, Moscow Humanitarian University Press, 2011, 166 p. (In Russian)

Kulakov A., ed. Not to Be Forgotten: Unknown Pages of Nizhny Novgorod History (1918-1984). Nizhnii Novgorod, Volgo-Viatskoe izdatel'stvo, 1994, 557 p. (In Russian)

Liagushkina L. Social Porter Repressed in the RSFSR during the Great Terror (1937-1938). Comparative Analysis of Databases on Regional Books of Memory. Diss. ... kand. ist. nauk. Moscow, 2016, 354 p. (In Russian)

Neumann M. The Communist League and the Transformation of the Soviet Union, 1917-1932. New York, Routledge, 2001, 312 p.

Serebrianskaia G. Industry and Personnel of the Volga-Vyatka Region of the Russian Federation in the late 30 s - first half of the 40 s of the $20^{\text {th }}$ Century. Nizhnii Novgorod, Nizhegorodskii gos. arkhit.-stroit. un-t, 2003, 473 p. (In Russian)

Trushchenko N. Kosarev. Moscow, Molodaia gvardiia, 1988, 399 p. (In Russian)

Vdovin M. All for Victory!: Essays on the History of the Defense Industry of the Gor'kovskaya Region: 19301945. Nizhnii Novgorod, Kvasrts Publ., 2010, 302 p. (In Russian)

Статья поступила в редакцию 30 августа 2018 г.

Рекомендована в печать 10 июня 2019 г.

Received: August 30, 2018

Accepted: June 10, 2019 